\title{
Linguistic Universals: Genetics or Proto-Language?
}

\section{Aldo Luiz Bizzocchi* \\ University of Sao Paulo, Brazil \\ *Corresponding author: Aldo Luiz Bizzocchi, University of Sao Paulo, Brazil}

\section{Opinion}

One of the most pressing issues in linguistic research is the so-called universals of language, elements or characteristics present in all natural languages, even those that have never had contact with each other nor have common ancestry. One of the foundations of science is precisely the possibility of finding general laws that govern all particular objects in a given domain. That all matter is made of atoms is a fundamental principle of physics; that all living beings reproduce is a universal of biology, and so on. In language, universal facts are those such as: all languages have a grammar; all are composed of words; every linguistic sign has a signifier and a signified.

But there are even more general facts, such as the observation that verbal language itself is universal: there is no people who preferentially communicates through a code other than words (such as whistles, gestures, touches). In other words, the very prevalence of verbal language is a universal and defining feature of the human species. So far, there is no doubt that it is a mechanism with biological roots: at some point in the evolution of the species, articulated verbal language emerged as a biological function beneficial to survival, which has since been transmitted genetically. This means that linguistic aptitude is somehow inscribed in our genes - which does not, of course, mean that the languages we speak are genetically inherited: obviously, this is learning. By the way, Daniel L. Everett, in the book How Language Began: The Story of Humanity's Greatest Invention, disputes the genetic character of linguistic aptitude, arguing that the gift of speech is a learned skill.

But the most basic structural characteristics of languages, added to the cognitive apparatus underlying them at a deeper level, suggest that every language develops and evolves according to a pattern that is not cultural but neurological. It's like saying that each language is a different software, but they all run on the same operating system and on the same hardware. This thesis, called linguistic innatism, was defended above all by Chomsky and the generativists and is gaining more and more strength with current studies in neuroscience and cognitive science.

But there is a difficult problem with regard to linguistic universals: vocabulary. It has long been known that certain words from the most primitive lexicon of languages, such as the terms for 'father' and 'mother', look remarkably similar, even in languages distant in time and space, languages that have never had contact with each other or demonstrate any trace of kinship. The presence of a phonetic element $p$ or $t$ (and its variants $f, b$ and $d$ ) in those words corresponding to 'father' and $\mathrm{m}$ or $\mathrm{n}$ in those corresponding to 'mother' (see table below) suggests that these terms came from prelinguistic childhood communication itself (babies in the prelinguistic phase babble things like pa, ta, ma, mama in front of their parents or asking to be breastfed) and, therefore, would be the result of genetic programming.

But the reconstruction of und ocumented dead languages by comparing documented languages led American linguist Merrit Ruhlen to the hypothesis that there would have been a proto-language, or mother of all languages, which he called proto-sapiens (one of the reconstructed words in this language would be tik 'finger'). That is, according to the theory that became known, in a somewhat derogatory way, as the "tower of Babel", all natural languages existing today would be remotely descended from a first language, spoken in Africa at the time of the emergence of the current human species, Homo sapiens (about 200,000 years ago). Although very controversial, this theory has many adherents and cannot be completely rejected.

The question then arises: do the words for 'father' and 'mother' look alike in most known languages because they are in our genetic code or because they have common ancestors in the proto-language? Is it biological or cultural heritage? In which cases was there transmission by loan 
and therefore linguistic contact and in which cases not? the next few years. And given the speed with which the Linguistics today has no sure answers to these questions, mass extinction of languages has taken place over the last but it is working hard to reach some conclusions within century, this is a race against time.

\begin{tabular}{|c|c|c|}
\hline \multicolumn{2}{|c|}{ "FATHER/MOTHER" IN DIFFERENT LANGUAGES OF THE WORLD } \\
\hline Albanian: babai/nëna & Hmong: txiv/niam & Nepali: bubā/āmā \\
Arabic: ab/am & Hungarian: apa/anya & Sesotho: ntati/'mè \\
Azeri: ata/ana & Kazakh: äke/ana & Swahili: baba/mama \\
Basque: aita/amak & Korean: abeolji/eomeoni & Thai: phx/mæ \\
Burmese: hpahkain/mihkain & Lao: pho/aem & Turkish: baba/anne \\
Cebuan: amahan/inahan & Latin: pater/mater & Uzbek: ota/ona \\
English: father/mother & Malay: bapa/ibu & Vietnamese: cha/me \\
Estonian: isa/ema & Malayalam: pitāv/am'ma & Welsh: tad/mam \\
Georgian: mama/deda & Mandarin: fùqin/mŭqin & Yoruba: baba/iya \\
Hebrew: abh/em & Maori: papa/whaea & Zulu: ubaba/umama \\
\hline
\end{tabular}

*Corresponding author: Aldo Luiz Bizzocchi, Email: aldo@aldobizzocchi.com.br

Next Submission with BGSR follows:

- Rapid Peer Review

- Reprints for Original Copy

- E-Prints Availability

- Below URL for auxiliary Submission Link: https://biogenericpublishers.com/submit-manuscript/ 